\title{
IDENTIFIKASI METODE PENANDAAN TERNAK KERBAU YANG DILEPASLIARKAN DI KABUPATEN ACEH TENGAH
}

\author{
(Identification of the Marking Methods of the Buffalo Livestock which Wild \\ Released in Aceh Tengah District)
}

\author{
Novida Sari ${ }^{1}$, Hamdan ${ }^{2}$ dan R.Edhy Mirwandhono ${ }^{2}$ \\ 1. Mahasiswa Program Studi Peternakan Fakultas Pertanian Universitas Sumatera Utara \\ 2. Staf Pengajar Program Studi Peternakan Fakultas Pertanian Universitas Sumatera Utara
}

\begin{abstract}
The results of this study were the farmers who did not use the mark on his livestock consisted of 78 farmers (38.4\%), and 125 farmers (61,58\%) has been used some different traditional methods to recording their livestocks. The most common method used wooden necklaces as many as $21,7 \%$, the bell necklaces sign as many as $19.2 \%$, the bamboo necklaces sign as many as $14.80 \%$ and rope necklaces sign as many as 5.9\%. The conclusion of this research is the identification of the marking methods of the buffaloes which wild released in Aceh Tengah District still used the traditional Recording methods and nearly a half of the farmers still did not used any marking material to their buffaloes.
\end{abstract}

Keywords : Identification, marking, livestock buffalo, wild released

\begin{abstract}
ABSTRAK
Hasil dari penelitian ini adalah penandaan pada ternak kerbau di kabupaten Aceh Tengah, peternak yang tidak menggunakan tanda pada ternaknya terdiri dari 78 peternak (38,4\%), dan sebagian besar yaitu 125 peternak $(61,5 \%)$ sudah menggunakan penandaan. Penandaan yang paling banyak dengan metode kalung yang terbuat dari kayu sebanyak 21,7\%, penggunaan tanda kalung lonceng sebanyak 19,2\%, tanda kalung bambu terdiri dari 30 peternak $14,80 \%$, dan penandaan yang paling sedikit menggunakan kalung dari tali terdiri dari peternak $12 \%$. Kesimpulan dari hasil penelitian ini adalah metode identifikasi penandaan ternak kerbau yang dilepasliarkan di daerah Aceh Tengah masih tradisional dan bahkan masih banyak juga peternak yang tidak menggunakan metode penandaan terhadap ternaknya.
\end{abstract}

Kata kunci : Identifikasi, Penandaan, Ternak Kerbau, Lepas liar.

\section{PENDAHULUAN}

Indonesia membentang sepanjang 5000 kilometer di daerah daerah tropik ekuator dari 17 derajat sampai 14 derajat bujur timur dan dari 2 derajat lintang utara sampai 13 derajat lintang selatan terdapat 13.000 pulau penyusun Indonesia dengan luas 203 juta hektar. Adanya berbagai berbagai macam musim, iklim, perbedaan topografi dan komposisi tanah mengakibatkan terdapatnya beraneka ragam tanaman yang tumbuh di Negara Indonesia. Hal ini justru menunjang kemungkinan perkembangan peternakan salah satunya peternakan kerbau (Bubalus bubalis). Perkembangan peternakan kerbau ini menyebar merata ke seluruh daerah kepulauan Indonesia terutama di daerah Aceh yang banyak memiliki aset peternakan 
kerbau yang bisa dikembangkan dan cukup dikenal dan diminati oleh masyarakat dataran aceh dan provinsi lainya.

Kerbau dapat berkembang dalam rentang agrosistem yang luas, oleh sebab itu kerbau ditemukan hampir diseluruh provinsi di Indonesia. Sebagian besar ternak kerbau diusahakan oleh peternak rakyat dengan manajemen pemeliharaan tradisional dan kualitas genetik masih rendah. Saat ini kerbau masih belum termanfaatkan secara maksimal walaupun sudah ada upaya di beberapa daerah untuk lebih meningkatkan pemanfaatannya. Pemanfaatan utama ternak kerbau sampai saat ini selain sumber daging juga merupakan ternak pekerja. Populasi kerbau di Indonesia pada tahun 2005 adalah 2.128.491 ekor, menurun menjadi 2.045.548 ekor pada tahun 2009 dan populasi kerbau lebih terpusat di Nangroe Aceh Darussalam, Sumatera Barat, Nusa Tenggara Barat, Banten dan Sumatara Utara, dimana sebagian besar kerbau dipelihara oleh peternak kecil dengan tingkat kepemilikan 2-3 ekor (Ditjen Peternakan, 2009).

Populasi kerbau di Indonesia berdasarkan statistik peternakan tahun 2008 yaitu sekitar 1,9 juta ekor (Ditjen Peternakan, 2008) tersebar di seluruh provinsi. Kerbau di Indonesia sebagian besar di peihara pada usaha tani kecil di pedesaan.

Kerbau adalah ternak asli daerah panas dan lembab, khususnya di daerah belahan utara tropika. Ternak kerbau sangat menyukai air. Kerbau lokal di Asia dikenal dengan beberapa istilah sesuai dengan daerahnya, antara lain Bhanis di India, Al-Jamoss di negaranegara Arab, Karbu di Malaysia dan Kerbau di Indonesia (Murti, 2002).

Kerbau adalah hewan ruminansia dari sub famili Bovidae yang berkembang di banyak bagian dunia dan diduga berasal dari daerah India. Kerbau domestikasi atau water buffalo berasal dari spesies Bubalus arnee. Spesies kerbau lain yang masih liar adalah $B$. mindorensis, B. depressicornis dan B. cafer (Hasinah dan Handiwirawan, 2006).

Kerbau adalah mamalia besar, kuat, berwarna gelap, dan bertanduk besar. Kerbau liar biasanya hidup dalam kelompok yang berisikan beberapa ekor dan suka tinggal di dekat air karena senang berlumpur. Kerbau air ditemukan di daerah basah Asia. Hanya sedikit yang masih liar, karena kebanyakan dipelihara manusia untuk membantu di ladang (Frandson, 1996).

Kerbau merupakan hewan ternak besar yang populasinya paling sedikit jika dibandingkan dengan sapi, kambing dan domba. Bahkan, dari tahun ketahun populasi kerbau pun semakin menurun. Ada beberapa penyebab penurunan jumlah populasi ternak kerbau ini yaitu diantaranya tingkat reproduksi yang rendah dan tingkat pemotongan kerbau itu sendiri yang sangat tinggi setiap tahunnya, yaitu 1,3\% per tahun (Susilawati dan Bustami, 2008). 
Ada dua bangsa kerbau yang diternakkan di dunia, yaitu kerbau lumpur (swamp buffalo) dan kerbau sungai (river buffalo). Kerbau lumpur memiliki 48 pasang kromosom dan kerbau sungai memiliki 50 pasang kromosom, walaupun berbeda dalam jumlah kromosom, tetapi perkawinan keduanya menurunkan keturunan yang juga fertil baik pada jantan maupun betina, hanya diduga bahwa daya reproduksi crossbreed tersebut lebih rendah dari masingmasing tetuanya (Talib, 2008).

Kerbau umumnya dipelihara secara tradisional di tempat-tempat khusus, seperti sungai, semak-belukar, pinggir hutan atau rawa. Hal ini menunjukkan bahwa kerbau belum banyak disentuh teknologi, sehingga peningkatan populasinya sangat lamban dibandingkan dengan ternak ruminansia lainnya (Baikuni, 2002). Kabupaten Aceh Tengah merupakan daerah dataran tinggi atau pegunungan dan masih terdapat banyak hutan semak belukar yang termasuk salah satu tempat yang di sukai oleh ternak kerbau sehingga cukup banyak petani yang memelihara ternak kerbau di Aceh Tengah. Pemeliharaan tenak kerbau merupakan sudah tradisi petani yang ada di Aceh Tengah hal ini disebabkan karna luasnya lahan di Kabupaten Aceh Tengah untuk terdapatnya ketersediaan pakan ternak seperti rumput segar yang terdapat di hutan sehingga hal inilah yang menyebabkan terdapat banyaknya populasi ternak kerbau di Kabupaten Aceh Tengah.

\section{BAHAN DAN METODE PENELITIAN}

\section{Tempat dan Waktu Penelitian}

Pelaksanaan penelitian ini dilaksanakan pada bulan Oktober 2013 sampai Januari 2014, di kecamatan Linge, Bintang dan Lut tawar Kabupaten Aceh Tengah.

\section{Bahan dan Alat Penelitian}

Bahan-bahan yang dibutuhkan dalam penelitian ini adalah buku bacaan sebagai bahan acuan penelitian, Peternak dan Ternak Kerbau yang berasal dari 3 Kecamatan di Kabupaten Aceh Tengah dan Alat-alat yang dibutuhkan dalam penelitian ini adalah alat tulis untuk mencatat hasil wawancara pada peternak dan kamera untuk dokumentasi lampiran penelitian.

\section{Metode Penelitian}

Metode penelitian yang digunakan dalam penelitian ini adalah dengan metode survei. Survei yang dilakukan adalah langsung ke peternakan rakyat. Ternak yang diteliti adalah

ternak kerbau. Mengidentifikasi metode penandaan yang digunakan peternak terhadap ternaknya dilaksanakan di rumah peternak dengan melakukan wawancara kepada peternak. 


\section{Metode Pengambilan Sampel}

Pengambilan sampel pada penelitian menggunakan metode slovin yang menjadi populasi adalah peternak yang memiliki ternak kerbau. Pemilihan sampel ditentukan secara proposive (sengaja) dengan kriteria sampel adalah Setiap Kecamatan yang sudah memiliki minimal 5 peternak kerbau. Besarnya jumlah sampel ditentukan dengan menggunakan Rumus Slovin jumlah sampel (Setiawan, 2007). Banyaknya sampel yang diambil dari 3 kecamatan yaitu kecamatan Linge yang berjumlah 582 Peternak, kecamatan Bintang berjumlah 465 Peternak, dan kecamatan Lut Tawar berjumlah 61 peternak.

Rumus slovin:

$$
\mathrm{n}=\frac{n}{n}
$$

Keterangan :

$\mathrm{n}=$ Ukuran sampel

$\mathrm{N}=$ Ukuran populasi

$\mathrm{e}=$ Kesalahan pengambilan sampel yang ditolerir $(10 \%)$

Jumlah Sampel Di Kecamatan Linge

$$
\begin{aligned}
\mathrm{n} & =\frac{584}{1+584(0.10)^{2}} \\
& =85.38 \\
& =85
\end{aligned}
$$

Jumlah Sampel Di Kecamatan Bintang

$\mathrm{n}=\frac{465}{1+465(0.10)^{2}}$

$\mathrm{n}=82.30$

$\mathrm{n}=82$

Jumlah Sampel Di Kecamatan Lut Tawar

$\mathrm{n}=\frac{61}{1+61(0.10)^{2}}$

$\mathrm{n}=37,8$

$\mathrm{n}=38$

Maka sampel yang diambil dari 3 kecamatan tersebut berjumlah 203 sampel. 


\section{Analisa Data}

Data yang terkumpul dan bersifat kualitatif dianalisis secara deskriptif dengan menggunakan analisa (Koefisien Keragaman) dan ditampilkan dalam persentase, sedangkan data yang bersifat kuantitatif dianalisis statistik dengan menggunakan Independent Sample Ttest dan dihitung standard error.

Metode penandaan pada ternak dilakukan dengan menghitung nilai rataan, simpangan baku (S), dan koefisien keragaman (KK) dari setiap sifat penandaan yang diamati (Sastrosupadi, 1995)..

$$
\bar{x} i=\frac{\sum_{\mathrm{i}=1}^{\mathrm{n}} \mathrm{xi}}{\mathrm{n}} \quad \mathrm{S}=\frac{\sum\left(\mathrm{x}_{\mathrm{i}}-\overline{\mathrm{x}}\right)^{2}}{\mathrm{n}-1} \quad \mathrm{KK} \%=\frac{\mathrm{s}}{\overline{\mathrm{x}}}(100 \%)
$$

Keterangan :

$\bar{x} \quad=$ Nilai rataan

$\mathrm{N} \quad=$ Jumlah sampel yang diperoleh

$\mathrm{Xi} \quad=$ Ukuran ke-i dari sifat penandaan $\mathrm{x}$

$\mathrm{S} \quad=$ Simpangan baku

$\mathrm{KK}=$ Koefisien keragaman

\section{Parameter Penelitian}

Parameter dalam penelitian ini adalah metode penandaan yang digunakan peternak kerbau (umur, lama beternak, dan jumlah ternak) di Aceh Tengah.

\section{HASIL DAN PEMBAHASAN}

\section{Profil Peternak Kerbau Di Aceh Tengah}

Setelah dilakukan survei di beberapa kecamatan di Aceh Tengah metode penandaan pada ternak kerbau yang dilepasliarkan hanya terdapat dengan cara pemberian identitas pada ternak tersebut sama halnya seperti yang umumnya dipakai di Indonesia, tidak ada metode penandaan dengan metode dokumentasi, catatan khusus, dan sertifikat tenak. Metode penandaan dengan pemberian identitas ini juga hanya dengan cara pemberian tanda pada ternak dengan cara sangat tradisional yaitu tanda berupa kalung atau peneng. Pemberian tanda pada ternak kerbau yang dilepasliarkan menggunakan kalung yang terdiri dari kalung lonceng, kalung bambu, kalung kayu, dan kalung tali. Metode penandaan ini dipengaruhi oleh profil Peternak, metode penandaan ternak, dan metode pemeliharaan ternak. 
Tabel 1. Rerata Jumlah Umur, Lama Beternak, dan Jumlah Ternak.

\begin{tabular}{lcccc}
\hline \multicolumn{1}{c}{ Parameter Penelitian } & Minimal & Maksimal & Rata-rata & Standar deviasi \\
\hline Umur (Tahun) & 28 & 85 & 50.82 & 10.325 \\
Lama Berternak (Tahun) & 2 & 57 & 15.14 & 12.333 \\
Jumlah Ternak (Ekor) & 2 & 37 & 10.54 & 6.045 \\
\hline
\end{tabular}

Seperti telah diketahui daerah Aceh Tengah merupakan daerah pegunungan sehingga masyarakat sebahagian besar berprofesi sebagai petani dan peternak. Kegiatan berternak dilakukan sudah secara turun temurun dari warisan keluarga peternak baik umur muda maupun sudah lanjut usia, hal ini dapat disajikan pada Tabel 1. yang merupakan dari hasil survei penelitian.

Data Tabel di atas diperoleh bahwa umur rata-rata Peternak sekitar 51 tahun dengan standar deviasi 10 tahun, umur terendah pada peternak adalah umur 28 tahun dan umur tertinggi 85 tahun. Hal ini menunjukkan bahwa peternak masih berada dalam kisaran umur produktif, meskipun ada beberapa peternak yang sudah masuk kategori umur tidak produktif. Umur peternak akan sangat berpengaruh terhadap mobilitas peternak dalam memelihara ternaknya, semakin muda maka akan semakin gesit, sehingga diharapkan dengan umur muda dan produktif peternak akan mampu memelihara ternaknya dengan baik dan produktivitas ternak akan meningkat (Murdjito, 2011).

Kegitan bertani yang diselingi dengan berternak sudah merupakan suatu tradisi turun temurun bahkan dari ratusan tahun lalu di daerah Kabupaten Aceh Tengah. Lama beternak bahkan mencapai puluhan tahun dilakukan oleh peternak, walaupun pemeliharaannya dilepasliarkan begitu saja. Lamanya berternak mempengaruhi manajemen pemelihara setiap ternak semakin lama akan menjadi suatu tradisi maupun sudah secara tradisi keluarga. Hal ini dapat dilihat pada Tabel 1 di atas.

Dari data tabel di atas diperoleh hasil lama rata-rata lamanya berternak kerbau di Kabupaten Aceh Tengah adalah selama 15 tahun dengan standar deviasi 12 tahun. Masa beternak yang paling singkat adalah slama 2 tahun dan waktu yang paling lama adalah sampai 57 tahun.

Banyaknya suatu jumlah ternak yang dimiliki oleh seorang peternak berpengaruh terhadap sistem penandaan yang dilakukan oleh setiap peternak karena dari hasil penelitian yang didapatkan jumlah rerata ternak yang dimiliki oleh setiap peternak dipengaruhi dengan semakin banyak jumlah ternak maka pemakaian tanda akan dibuat lebih banyak terhadap ternak tersebut. Banyaknya rerata jumlah tenak yang di miliki oleh setiap peternak dapat 
dilihat pada tabel 1 di atas. Dari tabel 1 diatas diperoleh hasil rerata jumlah ternak adalah minimal sebanyak 2 ekor dan maksimal 37 ekor dengan nilai rata-rata 10.54 dan dengan standar deviasi 6.045 .

Umur peternak, lama beternak dan jumlah setiap ternak yang di miliki oleh peternak merupakan faktor-faktor menentukan suatu metode beternak. Begitu juga dengan pendidikan terakhir setiap peternak, pendidikan setiap peternak diketahui dari hasil survei maksimal hanya sampai ke tahap Sekolah Menengah Atas (SMA) atau sederajat kita ketahui semakin tinggi tingkat pendidikan pengetahuan tentang beternak juga akan lebih dalam dan peternak juga akan lebih mengerti dalam pemeliharaan dan memanajemen ternak yang dimilikinya lebih kepada sistem moderen. Dari hasil penelitian ini tingkat pendidikan setiap peternak tidak ada satupun yang sampai ke jenjang sarjana hal ini juga merupakan salah satu faktor masih adanya ternak yang dipelihara secara dilepasliarkan. Pendidikan terakhir setiap peternak ini disajikan pada Tabel 2.

Tabel 2. Pendidikan Terakhir Peternak

\begin{tabular}{lcc}
\hline \multicolumn{1}{c}{ Pendidikan Terakhir } & Frekwensi & Persen $(\%)$ \\
\hline Tidak sekolah & 26 & 12.8 \\
Tamat SD & 23 & 11.3 \\
Tamat SMP & 64 & 31.5 \\
Tamat SMA & 90 & 44.3 \\
Total & 203 & 100.0 \\
\hline
\end{tabular}

Dari tabel 2 diperoleh hasil jumlah Pendidikan terakhir peternak tidak bersekolah sebanyak 26 orang (12.8\%), tamatan SD sebanyak 23 orang (11.3\%), tamatan SMP sebanyak 64 orang (31.5\%), dan tamatan SMA sebanyak 90 orang $(44.3 \%)$.

\section{Metode Penandaan Ternak}

Berdasarkan survei yang telah dilakukan diperoleh hasil seperti pada tabel ber3ikut ini.

Tabel 3. Deskripsi Penandaan Ternak Kerbau

\begin{tabular}{ccccc}
\hline \multicolumn{2}{c}{ Metode } & Frekwensi & Persen $(\%)$ & Total \\
\hline \multicolumn{6}{c}{ Tidak Bertanda } & 78 & 38.42 & 38.42 \\
\hline \multirow{4}{*}{ Bertanda } & Tali & 12 & 5.9 & \\
& Kayu & 44 & 21.7 & 61.58 \\
& Lonceng & 39 & 19.2 & \\
& Bambu & 30 & 14.8 & 100 \\
\hline
\end{tabular}


Dari hasil Tabel 3 dapat digambarkan dengan deskripsi berbentuk diagram seperti pada gambar di bawah ini.

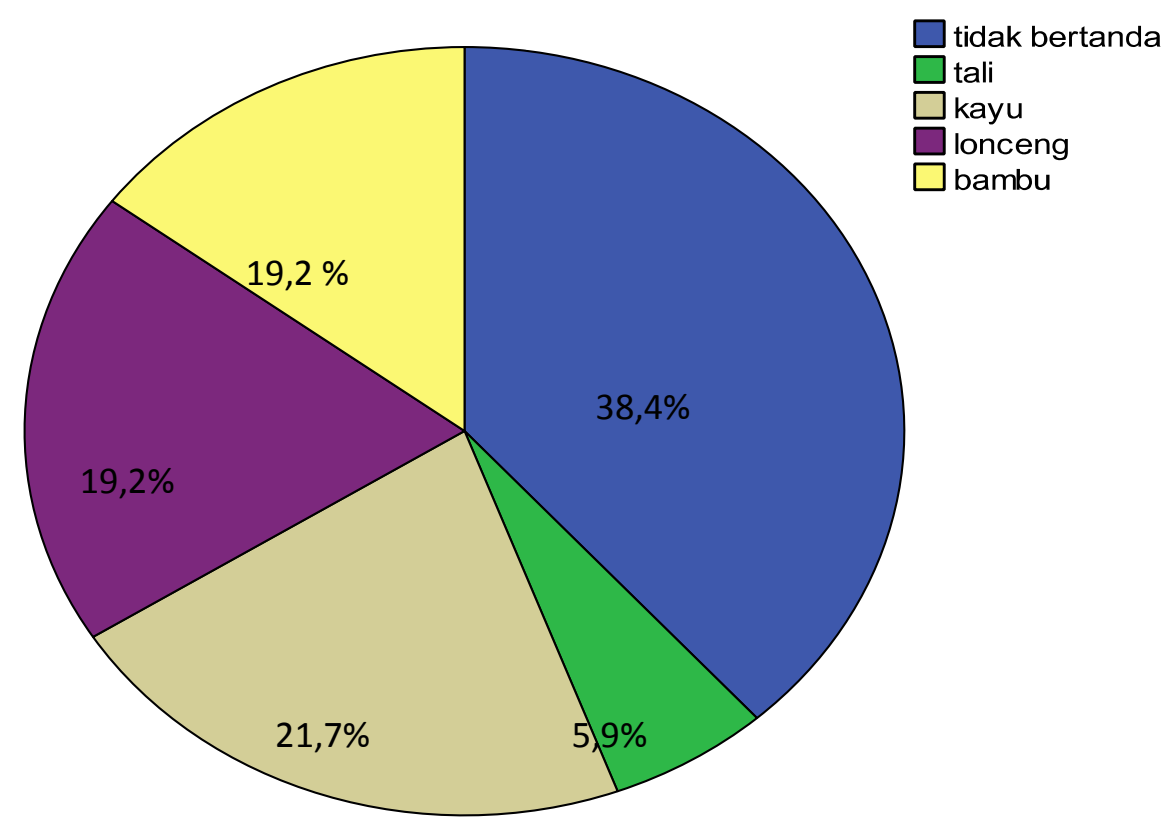

Gambar 1. Diagram Lingkaran Penandaan Ternak Kerbau

Berdasarkan Tabel 3 dan Gambar 1 metode penandaan pada ternak kerbau di kabupaten aceh tengah sebagian peternak tidak menggunakan tanda pada ternaknya terdiri dari 78 peternak $(38,4 \%)$, dan sebagian besar yaitu 125 peternak (61,5\%) sudah menggunakan penandaan. Penandaan yang paling banyak dengan metode kalung yang terbuat dari kayu sebanyak 44 peternak $(21,7 \%)$, penggunaan tanda kalung lonceng sebanyak 39 peternak $(19,2 \%)$, tanda kalung bambu terdiri dari 30 peternak $(14,80)$, dan penandaan yang paling sedikit menggunakan kalung dari tali terdiri dari 12 peternak $(5,9 \%)$.

Seperti diketahui Bahan Metode identifikasi Penandaan secara umum sangat penting kegunaannya bagi peternak kecil dan peternak besar, akan tetapi hal ini berbeda dengan kegunaannya terhadap peternak kerbau di Aceh tengah dilihat dari hasil penelitian kebanyakan peternak kerbau yang dilepasliarkan tidak menggunakan tanda pada ternaknya yang bisa dilihat pada Tabel 3 dan Gambar 1. Dari hasil survei penelitian hanya beberapa ekor saja ternak yang menggunakan tanda pada tubuhnya. Tidak banyak ditemui tanda-tanda khusus pada ternak kerbau yang dimiliki oleh setiap peternak di Aceh tengah. Biasanya ternak kerbau yang dimiliki peternak hidupnya berkelompok dan membuat kawanan sendiri. 
fungsinya tersebut bukan untuk identitas melainkan untuk panggilan suara bila anggota kawanan kerbau terpisah dari kelompoknya dan juga memudahkan pemilik untuk melacak keberadaan kerbau-kerbau tersebut. Karena tidak memiliki tanda-tanda khusus, hanya pemilik atau pawangnya saja yang mengetahui kerbau-kerbau yang dimilikinya.

Sejauh ini peternak kerbau yang dilepasliarkan tidak sulit mengenali kerbau yang dimilikinya bahkan adanya mencapai puluhan ekor pada tiap kawanan kerbau yang miliki setiap peternak. Sangat jarang terjadi kehilangan atau tertukar antara kerbau-kerbau yang dilepasliarkan tersebut. Jika terjadi ancaman pada ternak tersebut hanya pada binatang buas yang ada di hutan tersebut.

Dari Hasil penelitian terhadap proporsi jenis kelamin ternak juga berpengaruh besar terhadap salah satu metode penandaan peternak pada setiap ternaknya. Misalkan dalam satu kelompok kawanan kerbau jumlah 12 ekor diantara 12 ekor ternak tersebut ada terdapat 2 pejantan dan 10 betina.

Tabel 4. Proporsi Jumlah Kelamin Ternak.

\begin{tabular}{lcc}
\hline \multicolumn{1}{c}{ Jenis kelamin Ternak } & Jumlah & Persentase (\%) \\
\hline Jantan & 603 & $28.18 \%$ \\
betina & 1542 & $71.82 \%$ \\
Jumlah ternak & 2145 & $100 \%$ \\
\hline
\end{tabular}

Dari hasil Tabel 4 dapat digambarkan dengan deskripsi proporsi jumlah kelamin ternak kerbau berbentuk diagram seperti pada gambar di bawah ini.

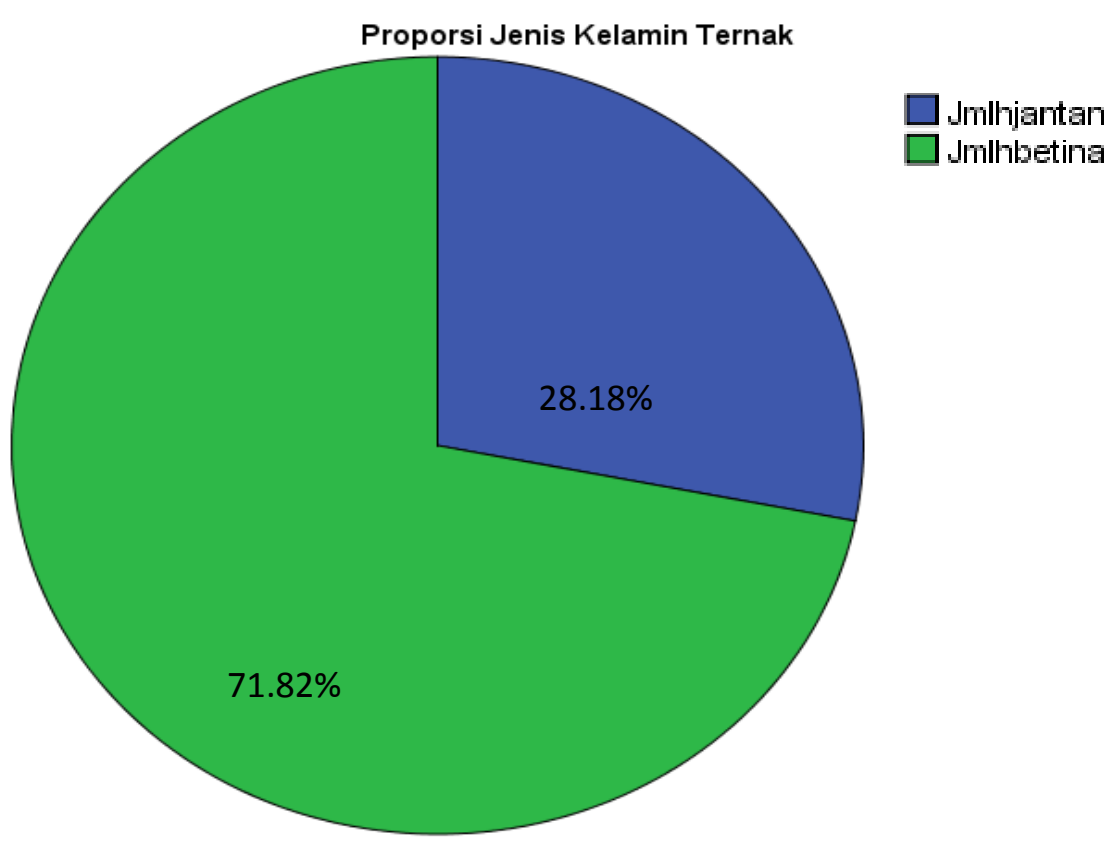

Gambar 2. Diagram Lingkaran Proporsi Jenis Kelamin Ternak. 
Kurangnya kemauan masyarakat untuk melaksanakan peternakan modern seperti di Negara lainya ternak tidak di manajemen dengan baik. Metode pemeliharaan setiap ternak sangat penting untuk proses manajemen peternakan sehingga tingkat pendidikan sangat berpengaruh pada Dari hasil analisa data tersebut terdapat jumlah ternak kerbau sebanyak 2.145 yang terdiri dari jumlah jantan sebanyak $603(28,18 \%)$ dan betina sebanyak 1.542 $(71,82 \%)$. Data tersebut diperoleh dari perhitungan jumlah ternak dari peternak-peternak yang telah diwawancarai.

Seperti diketahui bahwa sistem penandaan pada ternak kerbau yang dilepasliarkan di aceh tengah lebih banyak tidak menggunakan metode pemakaian tanda pada setiap ternaknya lebih banyak menandai ternaknya dari ciri-ciri fisik paling utama adalah dengan menggunakan menghitung jumlah jantan dan betina pada setiap kawanan kelompok ternaknya.

\section{Metode pemeliharaan}

Memelihara kerbau dengan cara dilepasliarkan di hutan sudah merupakan tradisi bagi masyarakat di Aceh tengah secara turun-temurun. Populasi ternak kerbau yang dilepasliarkan diperkirakan mencapai 10.000 ekor. Kerbau-kerbau tersebut dilepaskan begitu saja mencari makan, tinggal, dan hingga beranak-pinak di dalam hutan tersebut. karena hidupnya diliarkan di hutan, peternak tidak perlu repot membuatkan kandang dan mencari rumput atau menyediakan pakan untuk ternaknya tersebut. Pemilik kerbau baru menangkap kerbaunya jika saat dibutuhkan saja seperti dijual, disembelih jika ada upacara adat, atau hanya untuk keperluan tertentu lainnya.

Meskipun hidup di alam bebas pemilik ternak kerbau tidak pernak takut jika ternak kerbau yang dimilikinya tertukar, dicuri, dan di lukai oleh orang lain atau binatang buas lainnya walau terkadang sebagian ternak kerbau tersebut dimangsa oleh binatang buas yang ada di dalam hutan tersebut. selama puluhan tahun memelihara ternak cara seperti ini jarang sekali terjadi masalah bagi pemilik kerbau padahal seperti kita ketahui sering terjadi pencurian ternak di setiap wilayah. Menurut cerita masyarakat di Aceh Tengah, memang pemilik yang bukan orang sembarangan memiliki kaki tangan (pawang hutan) yang tersebar diwilayah tersebut yang merupakan sebuah cerita yang sudah menjadi kepercayaan dari masyarakat aceh tengah. Pawang tersebutlah yang menjadi pengawas dan penjaga dari kerbau-kerbau tersebut sehingga untuk mencuri atau melukai saja orang tidak berani. Selain takut berurusan dengan pemiliknya, kerbau-kerbau yang sudah terbiasa hidup liar ini sangat sulit untuk ditangkap hanya pawang tersebut yang mampu menangkapnya (Syukri,2012). Kepercayaan masyarakat yang masih terhadap cerita masyarakat setempat inilah yang membuat perkembangan peternakan yang baik. Semakin tingginya tingkat pendidikan 
semakin membuat pemikiran dalam memajukan peternakan di setiap daerah akan meningkatkan dan perkembangan ternak kerbau semakin berjalan baik dan berproduksi lebih banyak.

\section{Hubungan Umur, Pendidikan, Jumlah Ternak, dan Lama Berternak dengan Penggunaan Tanda pada Ternak.}

Untuk mengetahui hubungan umur, pendidikan, jumlah ternak, dan lama berternak dengan penggunaan tanda pada ternak maka akan dilakukan uji-T terhadap varibel yang bersangkutan tersebut. Uji-t (t-test) merupakan statistik uji yang sering kali ditemui dalam masalah-masalah praktis statistika. Uji-t termasuk dalam golongan statistika parametrik. Statistik uji ini digunakan dalam pengujian hipotesis. Uji-t digunakan ketika informasi mengenai nilai variance (ragam) populasi tidak diketahui. Uji-t adalah salah satu uji yang digunakan untuk mengetahui ada atau tidaknya perbedaan yang signifikan (meyakinkan) dari dua buah mean sampel (dua buah variabel yang dikomparasikan) (Hartono, 2008).

Variabel-variabel yang ingin dihubungan dari uji-t ini adalah hubungan antara umur dengan penggunaan tanda pada ternak, hubungan antara pendidikan dengan penggunaan tanda pada ternak, hubungan antara jumlah ternak dengan penggunaan tanda pada ternak, dan hubungan antara lama berternak dan penggunaan tanda pada ternak.

Tabel 5. Hasil Uji T Data

\begin{tabular}{lc}
\hline \multicolumn{1}{c}{ Variabel } & Nilai $\mathbf{p}(\mathbf{C I}=\mathbf{9 5 \%})$ \\
\hline Umur & 0,605 \\
Pendidikan & 0,701 \\
Jumlah Ternak & 0,020 \\
Lama Berternak & 0,304 \\
\hline
\end{tabular}

Berdasarkan hasil uji analisa $\mathrm{T}$ yang telah dilakukan di atas ditemukan bahwa ada hubungan bermakna antara jumlah ternak yang dimiliki peternak kerbau dengan penggunaan tanda pada kerbau $(\mathrm{p}=0,020)$ karena menurut ketentuan ilmu statistik jika nilai $\mathrm{p} \leq 0.05$ maka menunjukan ada hubungan dari kedua variabel tersebut, tetapi tidak ditemukan adanya hubungan yang bermakna antara umur $(\mathrm{p}=0,605)$, pendidikan $(\mathrm{p}=0,701)$, dan lama berternak $(\mathrm{p}=0,304)$ dengan penggunaan pada tanda pada kerbau karena dari ketentuan jika $\mathrm{p} \geq 0.05$ maka tidak ada menujukan hubungan antara kedua variabel tersebut. 


\section{KESIMPULAN}

Kesimpulan dari hasil penelitian ini adalah metode identifikasi penandaan ternak kerbau yang dilepasliarkan di daerah Aceh Tengah masih tradisional dan bahkan masih banyak juga peternak yang tidak menggunakan metode penandaan terhadap ternaknya.

\section{DAFTAR PUSTAKA}

Baikuni. 2002. Karakteristik reproduksi dan potensi pengembangan ternak kerbau di Kabupaten Musi Rawas, Provinsi Sumatera Selatan. Skripsi. Fakultas Peternakan, Institut Pertanian Bogor, Bogor.

Ditjennak, 2008. Data Populasi Kerbau dari: Statistika Pertanian. Direktorat Jenderal Peternakan, Jakarta.

Ditjennak, 2009. Perkembangan Kerbau di Indonesia. Direktorat Jenderal Peternakan, Jakarta.

Frandson, R. D., 1996. Anatomi dan Fisiologi Ternak, Edisi ke-7, diterjemahkan oleh Srigandono, B. dan Praseno, K. UGM Press, Yogyakarta.

Murdjito, G. 2011. Kinerja Kambing Bligon Yang Dipelihara Peternak Di Desa Giri Sekar, Panggang, Gunungkidul. Buletin Peternakan Vol. 35(2): 86-95. Fakultas Peternakan, Universitas Gadjah Mada, Yogyakarta.

Hartono, 2008. Statistik Untuk Penelitian. Yogyakarta. Lembaga Studi Filsafat Kemasyarakatan dan Perempuan.

Hasinah, H. dan Handiwirawan, 2006. Keragaman Genetik Ternak Kerbau di Indonesia. Pusat Penelitian dan Penegembangan Peternakan, Bogor..

Murti, T. W., 2002. Ilmu Beternak Kerbau. Kanisius, Yogyakarta.

Sastrosupadi, A., 1995. Rancanan Percobaan Praktis untuk Bidang pertanian. Kanisius, Yogyakarta.

Setiawan, N. Penentuan Ukuran Sampel Memakai Rumus Slovin Dan Tabel Krejcie-Morgan: Telaah Konsep Dan Aplikasinya, Fakultas Peternakan Universitas Padjadjaran, Bandung.

Susilawati, E. dan Bustami, 2008. Pengembangan Ternak Kerbau di Provinsi Jambi. Makalah. Bahan Pengkajian Teknologi Ternak, Jambi. Hal: 11 - 17

Syukri M, 2012. Ternak Kerbau Aceh Tengah. Diakses tanggal 20 Maret 2013 http://green.kompasiana.com/penghijauan/2012/04/30/garam-bikin-kerbau-pulangtepat-waktu-458778.html

Talib, C., 2008. Kerbau. Pusat Penelitian dan Pengembangan Ternak, Bogor. 